\title{
Korelasi antara Modification of Diet in Renal Disease (MDRD) dan Cystatin C Serum pada Usia 40-70 Tahun
}

\author{
Jason Jus, ${ }^{1}$ Ronald Irwanto, ${ }^{2}$ Pusparini ${ }^{3}$ \\ ${ }^{1}$ Prodi Profesi Dokter, Fakultas Kedokteran Universitas Trisakti, Jakarta, ${ }^{2}$ Bagian Ilmu Penyakit Dalam Fakultas \\ Kedokteran Universitas Trisakti, Jakarta, ${ }^{3}$ Bagian Patologi Klinik Fakultas Kedokteran Universitas Trisakti, \\ Jakarta
}

\begin{abstract}
Abstrak
Pelaporan estimasi laju filtrasi glomerulus (eLFG) pada setiap hasil pemeriksaan kreatinin dianjurkan, walaupun saat ini tidak semua laboratorium mencantumkan pada hasil pemeriksaan. Modification of Diet in Renal Disease (MDRD) merupakan formula yang digunakan untuk mengestimasi laju filtrasi glomerulus menggunakan kreatinin serum. Cystatin $\mathrm{C}$ serum merupakan pemeriksaan yang relatif baru dan petanda yang baik untuk menilai fungsi ginjal. Penelitian ini bertujuan mengetahui korelasi antara MDRD dan cystatin C serum. Penelitian ini menggunakan data sekunder dari 260 subjek penelitian usia 40-70 tahun yang memeriksakan kreatinin serum dan cystatin C serum selama periode Januari 2013-September 2014 di laboratorium klinik swasta di Jakarta Barat dengan desain potong lintang. Hasil penelitian menunjukkan bahwa usia rata-rata subjek 55,7 $\pm 7,8$ tahun. Kadar cystatin C serum rata-rata 0,99 $\pm 0,6 \mathrm{mg} / \mathrm{L}, \mathrm{MDRD} 80,24 \pm 28,1 \mathrm{~mL} / \mathrm{min} / 1,73 \mathrm{~m}^{2}$. Terdapat korelasi negatif antara MDRD dan cystatin $\mathrm{C}$ serum dengan $\mathrm{r}=-0,767, \mathrm{p}=0,001$ (uji Pearson). Disimpulkan bahwa semakin tinggi nilai MDRD, nilai cystatin $\mathrm{C}$ serum semakin rendah. MDRD dapat digunakan sebagai alternatif uji fungsi ginjal bila pemeriksaan cystatin C serum tidak tersedia. [MKB. 2016;48(3):129-34]
\end{abstract}

Kata kunci: Cystatin C, eLFG, kreatinin, MDRD

\section{Correlation between Modification of Diet in Renal Disease(MDRD) and Serum Cystatin C in 40-70 Years Old}

\begin{abstract}
Reporting of the estimated glomerular filtration rate (GFR) in every creatinine test is suggested, despite the fact that every laboratory reports it in their result. Modification of Diet in Renal Disease (MDRD) is a formula that is used to estimate the GFR using serum creatinine. Serum cystatin C is a relatively new test and superior for assessing kidney functions. The purpose of this study was to show the correlation between MDRD and serum cystatin C. A cross-sectional study was conducted using secondary data from 260 subjects, aged 40-70 years old to assess serum creatinine and serum cystatin $\mathrm{C}$ at a private laboratory in West Jakarta, during the period of January 2013-September 2014. The result of the study showed that the mean age of subjects was $55.7+7.8$ years old, the mean serum cystatin C level was $0.99+0.6 \mathrm{mg} / \mathrm{L}$, and the mean MDRD was $80.24 \pm 28.1 \mathrm{~mL} / \mathrm{min} / 1.73 \mathrm{~m} 2$. Pearson correlation analysis showed a negative correlation between MDRD and serum cystatin $C$ with $r=-0.767$ and $p=0.001$. In conclusion, higher MDRD presents lower cystatin $C$ serum; hence, MDRD can be used as an alternative renal function test when serum cystatin C is not available. [MKB. 2016;48(3):129-34]
\end{abstract}

Key words: Cystatin C, creatinine, eGFR, MDRD

Korespondensi: Jason Jus, S.Ked, Fakultas Kedokteran Universitas Trisakti Jakarta, Jalan Kyai Tapa Kampus B Usakti No. 260, Grogol, Jakarta Barat, mobile 081290362634, e-mail jason_jus@hotmail.com 


\section{Pendahuluan}

Kreatinin serum ialah merupakan pemeriksaan laboratorium yang digunakan untuk memeriksa kadar kreatinin di dalam tubuh. Kreatinin merupakan hasil metabolisme kreatinin pada fosfat otot dan diekskresikan melalui ginjal. Pemeriksaan kreatinin serum mempergunakan kreatinin yang diekskresikan melalui ginjal sebagai petanda untuk menilai fungsi ginjal. Penilaian fungsi ginjal menggunakan kreatinin serum dianjurkan oleh Kidney Disease Improving Global Outcome Chronic Kidney Disease Work Group untuk selalu disertai dengan penilaian estimasi laju filtrasi glomerulus (eLFG). ${ }^{1}$ Pelaporan eLFG pada setiap pelaporan hasil pemeriksaan kreatinin serum digunakan untuk deteksi dini kelainan fungsi ginjal. Penilaian eLFG dihitung menggunakan rumus yang dibuat berdasarkan atas berbagai penelitian sehingga mampu memperkirakan eLFG. Pemeriksaan eLFG mempergunakan kreatinin serum dapat menghasilkan overestimasi karena kreatinin serum diekskresikan tidak hanya melalui filtrasi dari glomerulus, tetapi juga sekresi tubulus sehingga pasien dianggap masih memiliki fungsi ginjal yang baik padahal fungsi ginjalnya sudah menurun. Salah satu formula yang dihasilkan untuk menilai LFG adalah formula Modification of Diet in Renal Disease (MDRD) yang dapat mempertimbangkan luas permukaan tubuh, ras, jenis kelamin, dan usia untuk mengurangi kemungkinan yang terjadi overestimasi dalam penghitungan eLFG. ${ }^{1,2}$

Cystatin C merupakan protein berukuran 13 kilodalton $(\mathrm{kD})$ yang diproduksi oleh seluruh sel berinti dan merupakan salah satu biomarker untuk prediksi LFG yang masih baru.$^{1,3}$ Kecepatan produksi protein ini tidak dipengaruhi oleh proses inflamasi, usia, jenis kelamin, dan status gizi. Protein ini juga difiltrasi dengan bebas oleh membran glomerulus dan direabsorbsi hampir sepenuhnya dan didegradasi oleh sel tubulus proksimal sehingga kadar cystatin $\mathrm{C}$ dalam plasma dipengaruhi khusus oleh LFG sehingga mempunyai potensi sebagai petanda eLFG yang sensitif. ${ }^{3-5}$

Kidney Disease Improving Global Outcome Chronic Kidney Disease Work Group dan Perkumpulan Nefrologi Indonesia (Pernefri) menganjurkan pelaporan eLFG pada setiap pemeriksaan kreatinin serum, tetapi sampai saat ini pemeriksaan eLFG berdasarkan hasil kreatinin serum belum banyak dilaporkan oleh laboratorium yang mengerjakan kreatinin serum. Pemeriksaan cystatin C serum untuk mendeteksi kelainan fungsi ginjal juga belum banyak dikerjakan di berbagai laboratorium. Penelitian ini bertujuan menganalisis korelasi antara penggunaan eLFG formula MDRD dan cystatin C serum sehingga dapat membantu mendeteksi secara dini kelainan ginjal ringan agar tidak berkembang menjadi kelainan ginjal berat dengan menggunakan eLFG pada setiap pemeriksaan fungsi ginjal.

\section{Metode}

Penelitian ini mempergunakan desain potong lintang. Penelitian ini dilakukan di Laboratorium Klinik Swasta di Jakarta Barat menggunakan data sekunder yang diambil dari bulan Januari 2013 sampai dengan bulan September 2014.Populasi penelitian ini adalah seluruh subjek yang memeriksakan kreatinin serum dan cystatin C serum di laboratorium klinik tersebut pada tahun 2013-2014. Perhitungan besar sampel menggunakan rumus:

$$
n=\left[\frac{(Z \alpha+Z \beta)}{0,5 \ln [(1+r) /(1-r)]}\right]^{2}+3
$$

Keterangan:

$\mathrm{n}$ = besarnya sampel adalah 32

$\mathrm{Z} \alpha=1,960$ untuk $\alpha=5 \%$

$\mathrm{Z} \beta=0,842$ untuk $\beta=20 \%$

$r=$ perkiraan koefisien korelasi adalah $0,806 .{ }^{6}$

Besar subjek minimal untuk penelitian ini adalah 32, tetapi pada penelitian ini diambil seluruh data subjek yang memeriksakan kreatinin serum dan juga cystatin C serum di laboratorium klinik tersebut dari Januari 2013September 2014. Kriteria inklusi penelitian ini adalah subjek yang memeriksakan kreatinin dan cystatin C serum, berusia 40-70 tahun. Kriteria eksklusi adalah tidak terdapat penghitungan eLFG dengan formula MDRD. Formula $\mathrm{MDRD}^{7}$ yang digunakan adalah:

eLFG $=175 \times$ standar kreatinin serum ${ }^{-1,154} \mathrm{x}$ usia $^{-0,203} \times 1,212^{\text {(Afrika Amerika) }} \times 0,742^{\text {(wanita) }}$

Nilai rujukan kadar kreatinin serum pada pria dan wanita adalah $0,5-1,2 \mathrm{mg} / \mathrm{dL}$ dan $0,4-$ $1,1 \mathrm{mg} / \mathrm{dL}$, cystatin $\mathrm{C}$ serum pada pria $0,48-0,98$ $\mathrm{mg} / \mathrm{L}$, pada wanita $0,51-0,94 \mathrm{mg} / \mathrm{L}$. Analisis data dilakukan menggunakan program statistical package for social sciences (SPSS) versi 17. Data 
univariat dianalisis mempergunakan analisis statistik deskriptif, yaitu distribusi frekuensi, persentase, rata-rata, dan juga standar deviasi (SD). Data bivariat dianalisis menggunakan uji korelasi Pearson bila didapatkan distribusi data normal. Bila distribusi data tidak normal dipergunakan uji korelasi Spearman. Untuk menentukan perbedaan antara kelompok usia dan kadar kreatinin serum, kadar cystatin C serum dan MDRD digunakan uji ANOVA. Pada analisis perbedaan rata-rata kelompok pria dan wanita dengan kadar kreatinin serum, cystatin C serum, dan MDRD digunakan uji-t independen. Penelitian ini telah dinyatakan lolos kaji etik oleh Komisi Etik Riset Fakultas Kedokteran Universitas Trisakti No. 177/KER-FK/X/2014.

\section{Hasil}

Dari Januari 2013 sampai dengan September 2014 terkumpul subjek yang memeriksakan kreatinin serum dan cystatin C serum sejumlah 260 orang. Karakteristik subjek penelitian dapat dilihat pada Tabel 1. Subjek penelitian terbanyak berusia antara 50 sampai 59 tahun, yaitu 114 orang $(43,8 \%)$. Jenis kelamin terbanyak pada penelitian ini adalah laki-laki, yaitu 166 orang

\section{Tabel 1 Karakteristik Subjek Penelitian} $(n=260)$

\begin{tabular}{lc}
\hline \multicolumn{1}{c}{ Karakteristik } & $\mathbf{x} \pm$ SD atau n (\%) \\
\hline $\begin{array}{l}\text { Usia, rata-rata } \\
\text { tahun } \pm \text { SD) } \\
40-49(\mathrm{n} / \%)\end{array}$ & $65,7 \pm 7,8$ \\
$50-59(\mathrm{n} / \%)$ & $114(43,8)$ \\
$>60(\mathrm{n} / \%)$ & $86(33,1)$ \\
$\begin{array}{l}\text { Jenis kelamin } \\
\text { Laki-laki n (\%) }\end{array}$ & $166(63,8)$ \\
$\quad$ Perempuan n (\%) & $94(36,2)$ \\
$\begin{array}{l}\text { Cystatin C (mg/L), rata- } \\
\text { rata } \pm \text { SD }\end{array}$ & $0,99 \pm 0.6$ \\
$\begin{array}{l}\left.\text { MDRD (mL/min/1,73 m }{ }^{2}\right), \\
\text { rata-rata } \pm \text { SD }\end{array}$ & $80,24 \pm 28,1$ \\
$\begin{array}{l}\text { Kreatinin (mg/L), rata- } \\
\text { rata } \pm \text { SD }\end{array}$ & $1,09 \pm 0,8$ \\
\hline
\end{tabular}

Keterangan: MDRD (modification of diet in renal disease), SD: standar deviasi
(63,8\%). Cystatin C serum rata-rata adalah 0,99 $\pm 0,6 \mathrm{mg} / \mathrm{L}, \mathrm{eLFG}$ dengan MDRD 80,24 $\pm 28,1$

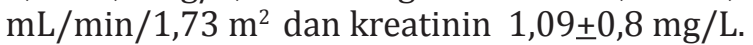
Pada Tabel 2 dapat dilihat subjek dengan usia 40 sampai 49 tahun memiliki cystatin C serum ratarata dan kreatinin serum rata-rata yang lebih rendah daripada kisaran usia lainnya. Makin tinggi usia maka kadar cystatin C serum makin meningkat dengan nilai $\mathrm{p}=0,015$ (Tabel 2). Kadar kreatinin juga meningkat seiring dengan meningkatnya usia, tetapi kadar kreatinin tertinggi rata-rata didapatkan pada usia 5059 tahun walaupun tidak berbeda bermakna dengan nilai $\mathrm{p}=0,155$ (Tabel 2). Sebaliknya, laju filtrasi glomerulus dengan MDRD yang tertinggi didapatkan pada usia yang makin muda, yaitu 40-49 tahun dengan nilai $\mathrm{p}=0,0001$ (Tabel 2). Tabel 2 juga memperlihatkan kadar cystatin C, MDRD, serta kreatinin berdasarkan jenis kelamin. Kadar cystatin C dan kreatinin pria lebih tinggi dibanding dengan wanita (nilai $\mathrm{p}=0,001$ ). Laju filtrasi glomerulus berdasarkan MDRD lebih tinggi pada wanita walaupun tidak terdapat perbedaan yang bermakna $(p=0,055)$. Gambar 1 menunjukkan korelasi antara MDRD dan cystatin C. Antara MDRD dan cystatin C serum menunjukkan korelasi negatif $(\mathrm{r}=0,767$; $\mathrm{p}=0,001$ ). Makin tinggi kadar cystatin $\mathrm{C}$ serum maka makin rendah laju filtrasi glomerulus.

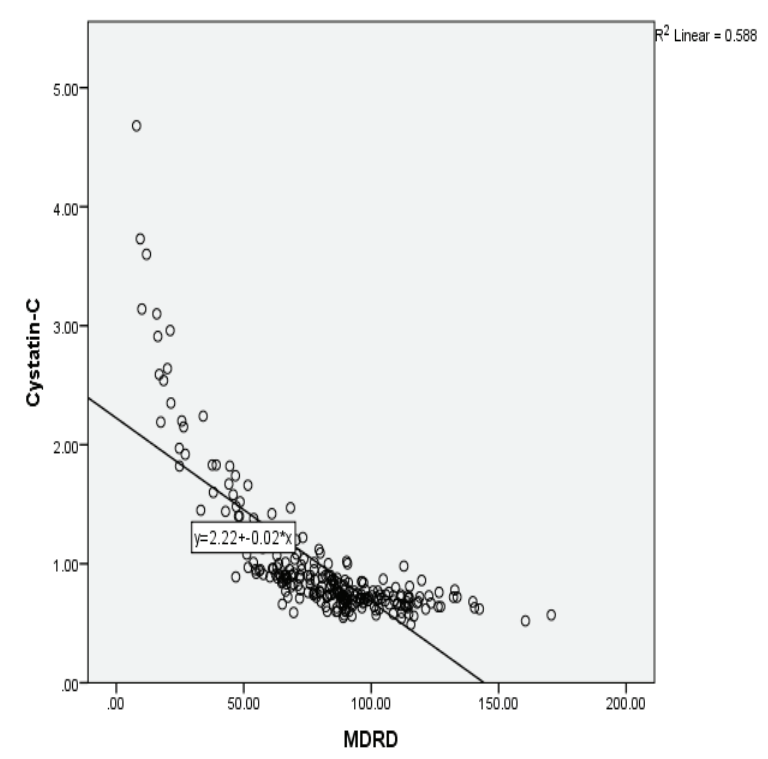

Gambar 1 Korelasi antara MDRD dan Cystatin C Semakin tinggi kadar cystatin C serum semakin rendah MDRD (laju filtrasi glomerulus) 
Tabel 2 Kadar Cystatin C, MDRD, dan Kreatinin berdasarkan Kelompok Usia dan Jenis Kelamin pada Usia 40-70 Tahun

\begin{tabular}{lccc}
\hline \multicolumn{1}{c}{ Karakteristik } & $\begin{array}{c}\text { Cystatin } C \\
(\mathbf{m g} / \mathbf{L})\end{array}$ & $\begin{array}{c}\text { MDRD } \\
\left(\mathbf{m L} / \mathbf{m i n} / \mathbf{1}, \mathbf{7 3} \mathbf{~ m}^{2}\right)\end{array}$ & $\begin{array}{c}\text { Kreatinin } \\
(\mathbf{m g} / \mathbf{L})\end{array}$ \\
\hline Usia (tahun) & & & \\
$\quad 40-49$ & $0,80 \pm 0,4$ & $92,36 \pm 23,6$ & $0,92 \pm 0.7$ \\
$50-59$ & $1,04 \pm 0,7$ & $80,29 \pm 30,6$ & $1,16 \pm 0.9$ \\
$\geq 60$ & $1,04 \pm 0,5$ & $71,72 \pm 24,5$ & $1,13 \pm 0,6$ \\
Nilai p & $0,015^{*}$ & $0,0001^{*}$ & 0,155 \\
Jenis kelamin & & & $1,27 \pm 0,9$ \\
$\quad$ Pria & $1,07 \pm 0,6$ & $75,29 \pm 28,3$ & $0,79 \pm 0,6$ \\
$\quad$ Wanita & $0,85 \pm 0,5$ & $88,21 \pm 25,9$ & $0,001^{*}$ \\
Nilai p & $0,001^{*}$ & 0,055 & \\
\hline
\end{tabular}

Keterangan: MDRD: modification of diet in renal disease. Nilai $\mathrm{p}<0,05$ berbeda bermakna (\# uji ANOVA, *uji-t independen)

\section{Pembahasan}

Pemeriksaan fungsi ginjal merupakan hal yang penting untuk mengetahui kemampuan ginjal menjalankan tugasnya. Kelainan yang terjadi pada ginjal dapat diketahui dari perubahanperubahan yang terjadi pada petanda fungsi ginjal seperti kreatinin dan cystatin C serum.

Penelitian ini dilakukan pada subjek yang berusia 40 sampai 70 tahun dengan usia rata-rata $55,7 \pm 7,8$ tahun (Tabel 1). MDRD pada penelitian ini adalah $80,24 \pm 28,1 \mathrm{~mL} / \mathrm{min} / 1,73 \mathrm{~m}^{2}$ (Tabel 1 ). Penelitian Ching dkk. ${ }^{8}$ mendapatkan hasil MDRD rata-rata sebesar $85.5 \pm 1,7 \mathrm{~mL} / \mathrm{min} / 1,73 \mathrm{~m}^{2}$ pada kelompok diabetes dan sebesar $95,1 \pm 0,6$ $\mathrm{mL} / \mathrm{min} / 1,73 \mathrm{~m}^{2}$ pada kelompok nondiabetes. Perbedaan MDRD rata-rata pada penelitian ini dan penelitian Ching dkk. ${ }^{8}$ mungkin disebabkan oleh perbedaan usia subjek dan populasi subjek penelitian. Usia subjek pada penelitian ini berkisar antara 40 sampai 70 tahun, sedangkan penelitian Ching dkk. ${ }^{8}$ mempergunakan subjek dengan usia lebih dari 20 tahun dengan usia rata-rata $58,2 \pm 1,1$ tahun pada penderita diabetes dan $45,2 \pm 0,4$ tahun pada penderita bukan diabetes. Populasi subjek penelitian pada penelitian Ching dkk. ${ }^{8}$ adalah penderita diabetes melitus dan bukan diabetes melitus, sedangkan pada penelitian ini subjek tidak dibedakan berdasarkan kelompok diabetes melitus (DM) maupun tidak diabetes melitus, hanya diambil dari data laboratorium pada semua subjek yang memeriksakan kadar kreatinin serum dan cystatin C serum. Hasil ini juga didukung oleh penelitian Lee dkk. ${ }^{9}$ yang menghasilkan MDRD rata-rata $78,6 \pm 21,3 \mathrm{~mL} / \mathrm{min} / 1,73 \mathrm{~m}^{2}$ dengan subjek berusia rata-rata $64 \pm 11,4$ tahun. Data yang dihasilkan memperlihatkan subjek yang lebih tua mempunyai MDRD yang lebih rendah sesuai dengan teori yang menyatakan bahwa makin tua usia makin rendah LFG. ${ }^{10,11}$ Faktor lain seperti kondisi penyakit tertentu seperti syok, GGA, diabetes melitus, dan hipertensi juga dapat membuat angka ekstrem pada LFG subjek penelitian. ${ }^{12}$ Peneliti mengambil data di laboratorium klinik yang sebagian besar pasiennya datang untuk melakukan medical check up atau sehat, sedangkan penelitian Ching dkk. ${ }^{8}$ mengambil data pada pasien yang memang sudah menderita penyakit diabetes melitus dan GGK.

Pada penelitian ini kadar cystatin $\mathrm{C}$ serum rata-rata adalah $0,99 \pm 0,6 \mathrm{mg} / \mathrm{L}$ (Tabel 1). Penelitian mengenai cystatin $\mathrm{C}$ yang dilakukan oleh Groesbeck dkk. ${ }^{13}$ pada usia antara 12 sampai 19 tahun mendapatkan hasil cystatin C rata-rata sebesar 0,84 $\pm 0,01 \mathrm{mg} / \mathrm{L}$, sedangkan penelitian yang dilakukan oleh Odden dkk. ${ }^{14}$ pada usia 65 sampai 100 tahun mendapatkan hasil cystatin C rata-rata sebesar 1,06 $\pm 0,34 \mathrm{mg} / \mathrm{L}$. Kadar cystatin $\mathrm{C}$ rata-rata meningkat seiring dengan peningkatan usia subjek.

Cystatin C serum rata-rata berdasarkan jenis kelamin didapatkan hasil pada pria sebesar $1,07 \pm 0,6 \mathrm{mg} / \mathrm{L}$, sedangkan pada wanita $0,85 \pm 0,5$ $\mathrm{mg} / \mathrm{L}$ (Tabel 2). Perbedaan jenis kelamin 
memperlihatkan pria mempunyai cystatin C serum lebih besar daripada wanita. Hasil yang didapat ini didukung oleh penemuan Groesbeck dkk. $^{13}$ yang menunjukkan cystatin $\mathrm{C}$ serum pada pria $0,89 \mathrm{mg} / \mathrm{L}$ dan wanita $0,79 \mathrm{mg} / \mathrm{L}$. Penemuan ini juga mendukung penelitian yang mendapatkan hasil bahwa cystatin C serum dipengaruhi oleh beberapa faktor seperti indeks massa tubuh, usia, penyakit yang diderita seperti nefritis, neoplasma ginjal, dan hipertensi. ${ }^{15}$

Kepentingan pemeriksaan fungsi ginjal terutama untuk dapat mengetahui secara dini penurunan fungsi ginjal yang ringan sehingga mencegah ke tingkat yang lebih berat., Pemeriksaan fungsi ginjal memakai kreatinin dipengaruhi oleh usia, jenis kelamin, massa otot, ukuran tubuh, makanan, konsumsi obat-obatan, serta metode pemeriksaan yang digunakan. Alasan inilah yang menyebabkan dipergunakan MDRD sebagai salah satu petanda fungsi ginjal yang mengonversikan hasil kreatinin serum menjadi perkiraan laju filtrasi glomerulus dengan mempertimbangkan berbagai aspek. ${ }^{17,18}$ Salah salah satu kekurangan pada pemeriksaan kreatinin serum yang dapat dilihat adalah kurang kemampuan untuk dapat mendeteksi penurunan fungsi ginjal yang ringan, meskipun begitu dengan menggunakan estimasi laju filtrasi glomerulus dari hasil penghitungan MDRD dapat mendeteksi kelainan fungsi ginjal secara dini. ${ }^{10}$

Kadar kreatinin rata-rata yang didapat pada penelitian ini adalah 1,09 $\pm 0,8 \mathrm{mg} / \mathrm{L}$ (Tabel 1). Terlihat pada peningkatan kadar kreatinin serum seiring dengan usia yang bertambah walaupun tidak didapatkan perbedaan yang bermakna. Keadaan ini disebabkan oleh fungsi ginjal akan menurun seiring dengan bertambahnya usia yang dapat dilihat dari penurunan laju filtrasi glomerulus sesuai dengan penambahan usia. ${ }^{10}$ Hasil kreatinin serum rata-rata yang didapat berdasarkan perbedaan usia memperlihatkan pria mempunyai kadar kreatinin serum yang lebih besar daripada wanita (Tabel 2). Perbedaan kadar kreatinin serum yang didapat merupakan hasil dari perbedaan massa otot yang dimiliki seseorang. Pria mempunyai massa otot yang relatif lebih besar daripada wanita sehingga kreatinin yang dihasilkan juga lebih banyak. Perbedaan kadar kreatinin serum pada jenis kelamin yang berbeda didapatkan juga pada penelitian Verma dkk. ${ }^{19}$

Korelasi antara MDRD dan cystatin C serum menunjukkan korelasi negatif (Gambar 1) dengan $r=-0,767$ dan $p=0,0001$. Hasil ini menunjukkan bahwa MDRD dapat digunakan sebagai alternatif uji fungsi ginjal di tempat pemeriksaan cystatin $\mathrm{C}$ serum tidak tersedia. Sampai saat ini di Indonesia masih belum mempunyai rumus estimasi laju filtrasi glomerulus yang berasal dari penelitian yang dilakukan di Indonesia sendiri sehingga hasil korelasi yang didapat masih berpotensi untuk memperlihatkan korelasi yang lebih tinggi apabila rumus MDRD untuk Indonesia sudah ditentukan. Penelitian Khorgami dkk. ${ }^{20}$ mendapatkan korelasi negatif antara cystatin $\mathrm{C}$ serum MDRD ( $r=-0,46$ dan $p<0,001)$. Perbedaan angka korelasi yang didapat merupakan hasil dari perbedaan subjek yang diperiksa. Peneliti mengambil data dari laboratorium klinik dan sebagian besar merupakan orang yang sehat, sedangkan Khorgami dkk. ${ }^{20}$ mengambil data dari subjek yang sudah menjalani hemodialisis.

Keterbatasan penelitian ini, data yang diambil merupakan data sekunder dari laboratorium sehingga subjek yang memiliki penyakit/suatu keadaan yang dapat menimbulkan bias pada hasil penelitian seperti sedang mengonsumsi obat, massa otot yang berlebihan, dan merokok tidak dapat diekslusikan karena peneliti tidak bertemu langsung dengan subjek.

Simpulan, apabila semakin tinggi nilai MDRD maka semakin rendah kadar cystatin $\mathrm{C}$ serum. Terdapat korelasi negatif antara MDRD dan cystatin $\mathrm{C}$ serum yang memperlihatkan bahwa penggunaan MDRD dapat menggantikan peran cystatin $\mathrm{C}$ serum dalam menunjukkan uji fungsi ginjal. Di Indonesia sebaiknya harus dilakukan penelitian untuk menentukan rumus MDRD untuk populasi di Indonesia sendiri. Diharapkan semua laboratorium yang memeriksa kreatinin serum mencantumkan eLFG pada hasil dari pemeriksaannya.

\section{Ucapan Terima Kasih}

Penulis mengucapkan terima kasih kepada kepada Manajemen PT. Prodia Widyahusada yang telah memberikan kesempatan untuk melakukan penelitian.

\section{Daftar Pustaka}

1. KDIGO. Clinical practice guideline for the evaluation and management of chronic kidney disease. Kidney Int. 2013;3(Suppl 1):S1-150.

2. Samra M, Abcar AC. False estimates of elevated creatinine. Pem J. 2012;16(2):51-2.

3. Grubb A, Bjork J, Nyman U, Pollak J, Bengzon J, Ostner G, dkk. Cystatin C, a marker for 
successful aging and glomerular filtration rate, is not influenced by inflammation. Scan J Clin Lab Invest. 2011;71(2):145-9.

4. Filler G, Bokenkamp A, Hofmann W, Bricon TL, Marthinez-bru C, Grubb A. Cystatinc as a marker of GFR: history, indications, and future research. Clin Biochem. 2005;38(1):18.

5. Peiris H, Chandrasena LG, Lanerolle RD. Serum cystatin $C$ as a marker to identify patients with moderately impaired renal function. Indian J Clin Biochem. 2008;23(2): 163-6.

6. Pucci L, Triscornia S, Lucchesi D, Fortino C, Pellegrini G, Pardini E, dkk. Cystatin C and estimates of renal function: searching for a better measure of kidney function in diabetic patients. ClinChem. 2007;53(3):480-8.

7. Levey AS, Coresh J, Greene T, Stevens LA, Zhang YL, Hendriksen S, dkk. Using standardized serum creatinine values in the MDRD study equation for estimating GFR. Ann Intern Med. 2006;145:247-54.

8. Ching WT, Grams ME, Inker LA, Coresh J, Selvin E. Cystatin C- and creatininebased estimated glomerular filtration rate, vascular disease, and mortality in persons with diabetes in the US. Diabetes Care. 2014;37(4):1002-8.

9. Lee JC, Kang IM, Chou CY, Tseng YH, Huang CC, Shih CM, dkk. Difference between estimated glomerulofiltration rate by modification of diet in renal diseases and cockcroftgaultformula in general population. J Intern Med Taiwan. 2009;20(2):148-54.

10. MeeusenJW, Rule AD, Voskoboev N, Baumann NA, Lieske JC. Cystatin C and creatinine based eGFR equation performance depends on patient characteristics. Clin Chem. 2015; 16(10):1265-72.

11. Tanaka A, Suemaru K, Araki H. A new approach for evaluating renal function and its practical application. J Pharmacol Sci.
2007;105(1):1-5.

12. KDIGO. Clinical practice guideline for the evaluation and management of acute renal failure. Kidney disease improving global outcome.KidneyInt.2012;2(Suppl1):S1-138.

13. Groesbeck D, Kottgen A, Parekh R, Selvin E, Schwartz GJ, Coresh J, dkk. Age, gender, and race effects on cystatin C levels in US adolescents. Clin J Am Soc Nephrol. 2008; 3(6):1777-85.

14. Odden MC, Tager IB, Gansevoort RT, Bakker SJL, Katz R, Fried LF, dkk. Age and cystatin C in healthy adults: a collaborative study. Nephrol Dial Transplant. 2010;25(2):463-9.

15. Wei L, Ye XS, Pei XH, Wu JQ Zhao WH. Reference intervals for serum cystatin $\mathrm{C}$ and factors influencing cystatin $\mathrm{C}$ levels other than renal function in the elderly. Plos One. 2014;9(1):1539-49.

16. Ali A, Asif N, Rais Z. Estimation of GFR by MDRD formula and its correlation to cockroftgaultequation in five stages of chronic kidney disease. J Nephrol. 2013;3(1):37-40.

17. Milic R, Colombini A, Lombardi G, Lanteri P, Banfi G. Estimation of glomerular filtration rate by MDRD equation in athletes: role of body surface area. Eur J Appl Physiol. 2012;112(1):201-6.

18. Caroll LE. The stages of chronic kidney disease and the estimated glomerular filtration rate. J Lancaster Gen Hosp. 2006;1(2):64-9.

19. Verma M, Khadapkar R, Sahu PS, Das BR. Comparing age-wise reference intervals for serum creatinine concentration in a "reality check" of the recommended cut-off. Indian J Clin Biochem. 2006;21(2):90-4.

20. Khorgami Z, Abdollahi A, Soleimani S, Ahamadi F, Mazdeh MM. Relationship between serum cystatin $\mathrm{C}$ and creatinine or dialysis adequacy in patients on chronic maintenance hemodialysis. Nephro Urol Mon. 2013;5(2):733-5. 